\title{
Interleukin-32-induced thymic stromal lymphopoietin plays a critical role in macrophage differentiation through the activation of caspase- 1 in vitro
}

Hyun-Ja Jeong ${ }^{1 \dagger}$, Sun-Young Nam ${ }^{2 \dagger}$, Hyun-A Oh², Na-Ra Han², Young-Sick Kim², Phil-Dong Moon ${ }^{2 *}$, Seung-Youp Shin ${ }^{3}$, Min-Ho Kim ${ }^{4}$ and Hyung-Min Kim² ${ }^{*}$

\begin{abstract}
Introduction: Interleukin (IL)-32 is an inflammatory cytokine induced by Mycobacterium tuberculosis and Mycobacterium bovis in a variety of cell types and discovered in the synovial of patients with rheumatoid arthritis (RA). Thymic stromal lymphopoietin (TSLP) play several roles in the pathogenesis of RA. However, the role of IL-32 and TSLP in RA has not been elucidated.

Methods: We evaluated the specific mechanism of between IL-32 and TSLP in RA using human monocyte cell line, THP-1 cells.

Results: Here we documented for the first time that IL-32 highly increased TSLP production in THP-1 cells and human blood monocytes. TSLP expression was induced by IL-32 via activation of caspase- 1 and nuclear factor- $\kappa \mathrm{B}$. TSLP produced by IL-32 increased differentiation of monocytes but depletion of TSLP prevented differentiation of monocytes into macrophage-like cells. Chondroprotective drugs such as chondroitin sulfate (CS) and the traditional Korean medicine, BaekJeol-Tang (BT) decrease production of TSLP and activation of caspase-1 and nuclear factor- $\kappa$ B. In addition, CS and BT inhibited IL-32-induced monocytes differentiation.
\end{abstract}

Conclusions: Taken together, IL-32 and TSLP are important cytokines involved in the development of RA. The effects of CS and BT were associated with the downregulation of TSLP and caspase-1 through negative regulation of IL-32 pathways in RA.

\section{Introduction}

Rheumatoid arthritis (RA) is characterized by a chronic inflammation of synovial joints that leads to a progressive destruction of articular and periarticular structures, causing severe morbidity and disability [1]. In RA, the extensive infiltration of inflammatory cells into the synovium and the tumor-like proliferation of RA synovial fibroblasts (RASF) cause the formation of a hyperplastic pannus, which aggressively invades and destroys underlying cartilage and bone. Until now, the role of macrophages, $\mathrm{T}$ and

\footnotetext{
* Correspondence: pdmoon@khu.ac.kr; hmkim@khu.ac.kr

† Contributed equally

${ }^{2}$ Department of Pharmacology, College of Oriental Medicine, Kyung Hee University, 1 Hoegi-dong, Dongdaemun-gu, Seoul 130-701, Republic of Korea Full list of author information is available at the end of the article
}

B cells, neutrophils, and RASF in the pathophysiology of RA have been examined extensively [2-6].

Interleukin (IL)-32 is a recently described cytokine produced by $\mathrm{T}$ lymphocytes, natural killer cells, epithelial cells, mast cells, keratinocytes, eosinophils, and blood monocytes [7-11] and was discovered in the synovial of patients with rheumatoid arthritis but not osteoarthritis [12]. IL-32 was induced by Mycobacterium tuberculosis and Mycobacterium bovis bacillus Calmette-Guérin as well as by either lipopolysaccharide (LPS) or mycobacteria [13]. Moreover, IL-32 production induced by M. tuberculosis is dependent on endogenous interferon- $\gamma$ (IFN- $\gamma$ ) [13]. A recent study demonstrated that overexpression of the inflammatory mediator, cyclooxygenase 2 resulted in

\section{() BiolMed Central}

(C) 2012 Jeong et al.; licensee BioMed Central Ltd. This is an open access article distributed under the terms of the Creative Commons Attribution License (http://creativecommons.org/licenses/by/2.0), which permits unrestricted use, distribution, and reproduction in any medium, provided the original work is properly cited. 
increased IL-32 levels [14]. IL-32 induces the production of tumor necrosis factor (TNF)- $\alpha$, IL- $1 \beta$, IL- 6 , and IL- 8 by means of the activation of nuclear factor (NF) $-\kappa \mathrm{B}, \mathrm{p} 38$ mitogen-activated protein kinase (MAPK), and caspase-1 $[7,8,11]$. IL-32 also modulates the signals induced by specific Toll-like receptors (TLRs) and nucleotide oligomerization domain (NOD) ligands. IL-32 synergized with NOD1 and NOD2 ligands for the synthesis of IL-1 $\beta$ and IL- 6 via activation of caspase-1 [8].

Thymic stromal lymphopoietin (TSLP) is associated with RA, allergic rhinitis and atopic dermatitis [15-17]. It might initiate $\mathrm{T}$ helper cell type 2 (Th2) polarization through an OX40-dependent mechanism that affects dendritic cells (DC) activity $[17,18]$. Signaling of cells by TSLP requires IL-7 receptor [19]. and a distinctive receptor subunit, the TSLP receptor (TSLPR), which is expressed by myeloid DC, monocytes, preactivated T cells, natural killer cells, and mast cells [18,20-22]. In humans, TSLP potently stimulates myeloid DC, with upregulated expression of CD40, CD80, CD86, OX40L, and CD83 and production of chemokines, including thymus and activation-regulated chemokine and macrophage-derived chemokine [23,24]. TSLP was expressed by TNF- $\alpha$ and IL- $1 \beta$ in human airway smooth muscle cells via MAPK, p38 and extracellular signal-regulated kinase (ERK) signaling pathway [25]. Recently, we reported that TSLP was expressed and produced by caspase- 1 and NF- $\kappa$ B activation in mast cells [26].

Although the above-mentioned findings indicate a likely role of IL-32 and TSLP in RA, the specific mechanism of between IL-32 and TSLP have not previously been studied. In this study, we report that IL-32 induces TSLP production and monocyte-to-macrophage differentiation through caspase-1. We also investigated the effect of useful therapeutic agents in RA, chondroitin sulfate (CS) and the traditional Korean medicine, BaekJeol-Tang (BT), in IL-32-induced TSLP production and monocyte differentiation.

\section{Materials and methods Reagents}

We purchased 3-(4,5-dimethylthiazol-2-yl)-2,5-diphenyltetrazolium bromide (MTT), bicinchoninic acid, caspase-1 inhibitor (CI), pyrrolidine dithiocarbamate (PDTC), lipopolysaccharide (LPS), dimethyl sulfoxide (DMSO), CS, and caspase-1 inhibitor from Sigma-Aldrich (St. Louis, MO, USA); recombinant IL-32, recombinant TSLP, caspase-1 assay kit, and recombinant caspase- 1 from R\&D Systems (Minneapolis, MN, USA); NF- $\kappa \mathrm{B}$, actin, histone, and caspase-1 antibodies from Santa Cruz Biotechnology (Santa Cruz, CA, USA); CD11b and CD14 antibodies from eBioscience (San Diego, CA, USA); TSLP SMART pool from Dharmacon Inc. (Chicago, IL, USA).

\section{Preparation of BT and CS}

BT is composed of shark cartilage (24 g), Atractylodis Rhizoma (Atractylodes lancea De Candolle, 8 g), Phellodendri Cortex (Phellodendron amurense Ruprecht, 8 g), and Sophora Radix (Sophora flavescens Solander ex Aiton, 8 g). BT (voucher number 201101) was obtained from TeunTeunMaDi Korean Medical Clinic (Seoul, Republic of Korea) and identified by Dr Hyung-Min Kim of the College of Oriental Medicine, Kyung Hee University. An extract of BT was prepared by decocting the dried prescription of herbs with boiling distilled water $(48 \mathrm{~g} / \mathrm{l})$. The product was filtered, lyophilized and kept at $4^{\circ} \mathrm{C}$. The yield of dried product from starting materials was about $35.6 \%$. CS is a major component of shark cartilage. The samples were dissolved in distilled water and then filtered through a $0.22 \mu \mathrm{m}$ syringe filter.

\section{Cells}

Human monocyte cell line, THP-1 was obtained from the American Type Culture Collection (TIB-202; Manassas, VA, USA). THP-1 cells were cultured in RPMI 1640 supplemented with $10 \%$ fetal bovine serum (FBS) and $2 \mathrm{mM}$ glutamine and were maintained at a concentration between 2 and $10 \times 10^{5}$ cells per milliliter.

\section{Isolation of peripheral blood mononuclear cells (PBMCs)}

PBMCs were isolated from healthy human volunteers. The donors were free of prescribed and over-the-counter medications. After informed consent, PBMCs from heparinized venous blood were isolated with Ficoll gradient centrifugation according to the manufacturer's specification (SigmaAldrich, MO, USA). This study was approved by the local ethics committee of Kyung Hee University Hospital in Seoul, Republic of Korea (KMC IRB 1222-06)

\section{TSLP assay}

THP-1 cells were treated with various concentrations of IL-32 for $24 \mathrm{~h}$. The production of TSLP was measured from cells culture supernatant according to the manufacturer's specifications (R\&D Systems, Minneapolis, MN, USA).

\section{Reverse transcription PCR analysis}

Using an easy-BLUETM RNA extraction kit (iNtRON Biotechnology, Republic of Korea), we isolated the total RNA from THP-1 cells in accordance with the manufacturer's specification. The concentrations of total RNA in the final elutes were determined by spectrophotometer. Total RNA ( $1 \mathrm{mg}$ ) was heated at $65^{\circ} \mathrm{C}$ for $10 \mathrm{~min}$ and then chilled on ice. Each sample was reverse-transcribed to cDNA for $90 \mathrm{~min}$ at $37^{\circ} \mathrm{C}$ using a cDNA synthesis kit (Amersham Pharmacia Biotech, Piscataway, NJ, USA). The PCR was performed with the following primer for 
human TSLP (5' TAT GAG TGG GAC CAA AAG TAC CG 3'; 5' GGG ATT GAA GGT TAG GCT CTG G 3') and GAPDH (5'CAA AAG GGT CAT CAT CTC TG 3'; 5'CCT GCT TCA CCA CCT TCT TG 3'). The annealing temperature was $62^{\circ} \mathrm{C}$ for TSLP and GAPDH. Products were electrophoresed on a $2 \%$ agarose gel and visualized by staining with ethidium bromide.

\section{Quantitative real-time PCR analysis}

Quantitative real-time PCR was performed using a SYBR Green Master Mix and the detection of mRNA was analyzed using an ABI StepOne Real-Time PCR System (Applied Biosystems, Foster City, CA, USA). Primer sequences for the reference gene GAPDH and the genes of interest were as follows: GAPDH (5'TCG ACA GTC AGC CGC ATC TTC TTT 3'; 5'ACC AAA TCC GTT GAC TCC GAC CTT 3'); human TSLP (5 CCC AGG CTA TTC GGA AAC TCA G 3'; 5' CGC CAC AAT CCT TGT AAT TGT G 3'); human CD11b (5'ACG TAA ATG GGA CAA GCT G 3'; 5'GAT CCT GAG GTT CCG TGA AA 3'); human CD14 (5'ACT TGC ACT TTC CAG CTT GC 3'; 5'GCC CAG TCC AGG ATT GTC AG 3'). Typical profile times used were the initial step, $95^{\circ} \mathrm{C}$ for $10 \mathrm{~min}$ followed by a second step at $95^{\circ} \mathrm{C}$ for $15 \mathrm{~s}$ and $60^{\circ} \mathrm{C}$ for 30 $\mathrm{s}$ for 40 cycles with a melting curve analysis. The level of target mRNA was normalized to the level of the GAPDH and compared with the control. Data were analyzed using the $\Delta \Delta C T$ method.

\section{Caspase- 1 enzymatic activity assay}

Caspase-1 enzymatic activity was measured according to the manufacturer's specification by using a caspase assay kit.

\section{Western blot analysis}

The stimulated cells were lysed and separated through $10 \%$ SDS-PAGE. After electrophoresis, the protein was transferred to nitrocellulose membranes and then the membranes were blocked and incubated with primary and secondary antibodies. Finally, the protein bands were visualized by an enhanced chemiluminesence assay purchased from Amersham Co. (Newark, NJ, USA) following the manufacturer's instructions.

\section{Transient transfection and luciferase assay}

For the transfection, we seeded THP-1 cells $\left(1 \times 10^{7}\right)$ in a $100 \mathrm{~mm}$ culture dish. We then used Lipofectamine ${ }^{\mathrm{TM}}$ 2000 purchased from Invitrogen (Carlsbad, CA, USA) to transiently transfect $\mathrm{pNF}-\kappa \mathrm{B}$ luciferase (LUC) and pSV40-LUC reporter gene constructs into THP-1 cells. To measure the luciferase activity, we used a luminometer 1420 luminescence counter purchased from Perkin Elmer (Waltham, MA, USA) in accordance with the manufacturer's protocol. All the transfection experiments were performed in at least three different experiments, with similar results. The relative luciferase activity was defined as the ratio of firefly luciferase activity to renilla luciferase activity.

\section{Analysis of monocyte surface antigens by flow cytometry and confocal laser scanning microscopy}

THP-1 cultured in the presence or absence of IL-32, TSLP, CI, CS, and BT for 6 days were washed in fluorescence-activated cell sorter (FACS) buffer (phosphatebuffered saline supplemented with $1 \%$ bovine serum albumin and $0.1 \% \mathrm{NaN}$ ) and then incubated with $2 \mu \mathrm{l}$ of fluorescein isothiocyanate (FITC)-conjugated CD14 and phycoerythrin (PE)-conjugated $\mathrm{CD} 11 \mathrm{~b}$ antibodies for $30 \mathrm{~min}$ at $4^{\circ} \mathrm{C}$. After washing with FACS buffer, cells were fixed with $1 \%$ (weight/volume) paraformaldehyde for $30 \mathrm{~min}$ and then stored in the dark until analyzed by flow cytometry. Cytofluorometry was performed with a FACScan (Becton Dickinson, Mountain View, CA, USA). All specimens were examined with a confocal laser scanning microscope.

\section{Statistical analysis}

All results are expressed as the mean \pm SEM. The statistical evaluation of the results was performed by an independent $t$ test and an ANOVA with a Tukey post hoc test. The results are significant with a value of $P<0.05$.

\section{Results}

Upregulation of TSLP production and mRNA expression in IL-32-treated THP-1 cells

IL-32 and TSLP levels are increased in patients with RA $[12,15]$. To identify the relationship between IL-32 and TSLP in RA, we investigated whether the mRNA of TSLP were expressed by IL-32 in THP-1 cells. When we stimulated the THP-1 cells with IL-32 of various concentrations, the TSLP mRNA was expressed (Figure 1A and 1B). LPS also induced expression of TSLP mRNA. IL-32 significantly increased TSLP production in a time-dependent manner (Figure 1C). TSLP production was significantly increased by IL-32 $(0.1$ and $1 \mu \mathrm{g} / \mathrm{ml})$ in a dose-dependent manner (Figure 1D, $P<0.05$ ). In our previous work, we reported that IL-32 produced IL-1 $\beta$. IL-1 $\beta$ production was assayed to test the activity of IL-32. IL-1 $\beta$ production was significantly increased by IL-32 (Figure $1 \mathrm{E}, P<0.05$ ). IL$32(1 \mu \mathrm{g} / \mathrm{ml})$ also significantly increased TSLP production in PBMCs (Figure 1F, $P<0.05$ ).

\section{Caspase-1 and NF- $\kappa$ B involvement in IL-32-induced TSLP production and $\mathrm{mRNA}$ expression}

Recently, we reported that TSLP was produced and expressed by caspase- 1 and NF- $\kappa$ B activation in mast cells [26]. To evaluate whether IL-32 increased caspase-1 and NF- $\kappa$ B activity in THP-1 cells, we performed Western blot 


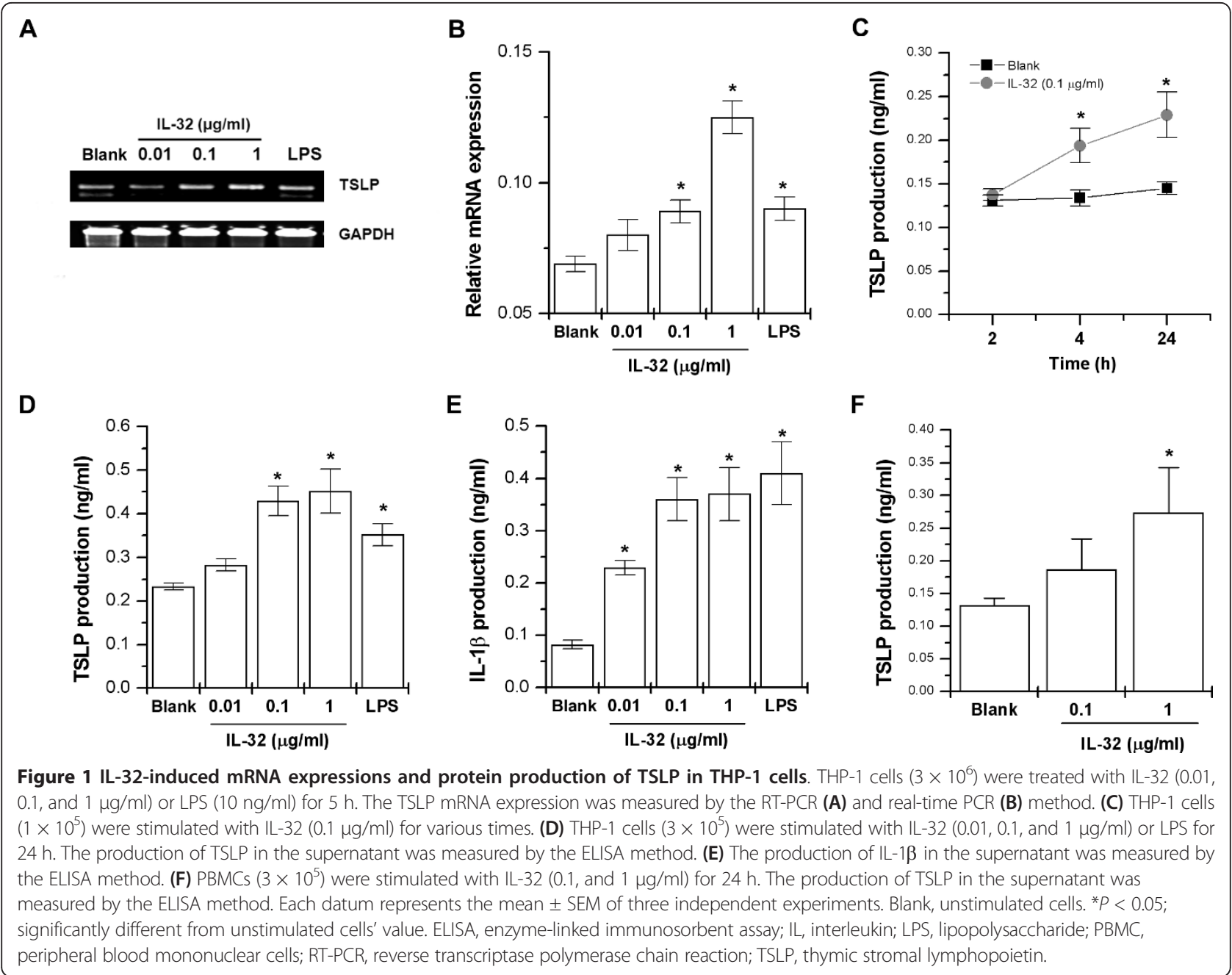

analysis and caspase- 1 assay. As shown in Figure 2A, IL-32 increased caspase- 1 and NF- $\kappa$ B activation. Caspase- 1 activity increased by IL-32 was inhibited by caspase- 1 inhibitor (Figure $2 \mathrm{~B}$ ). TSLP and IL-1 $\beta$ production increased by IL-32 $(0.1 \mu \mathrm{g} / \mathrm{ml})$ was dose-dependently inhibited by treatment of caspase- 1 inhibitor (Figure $2 \mathrm{C}, P<0.05$ ). NF- $\kappa \mathrm{B}$ inhibitor, PDTC, inhibited IL-32-induced NF- $\kappa$ B activation and TSLP mRNA expression (Figure 2D). LPS also induced TSLP production through caspase- 1 and NF- $\kappa \mathrm{B}$ activation in THP-1 cells.

Role of caspase-1 in IL-32-induced macrophage-like cells differentiation

Netea et al. reported that IL-32 induces differentiation of monocytes into macrophage-like cells [27]. As shown in Figure 3A, IL-32-treated cells appeared differentiated into macrophages. In contrast, caspase-1 inhibitor blocked IL-32-induced differentiation (Figure 3A). Next, we performed detailed analyses of macrophage markers. As shown in Figure 3B, IL-32 induced transcription of both CD11b and CD14 mRNA but caspase-1 inhibitor significantly reduced CD11b and CD14 mRNA levels in THP-1 cells (Figure 3B). To observe the consistency of the IL-32 effect on surface markers of the macrophage phenotype, THP-1 cells were incubated with IL-32 for 6 days, and the protein expression of CD11b and CD14 was analyzed by FACS. As shown in Figure 3C, IL-32 induced a consistent increase in the protein expression of both CD11b and CD14 compared with control cells incubated with medium only. In contrast, caspase-1 inhibitor reduced $\mathrm{CD} 11 \mathrm{~b}$ and $\mathrm{CD} 14$ protein expression (Figure $3 C)$. When THP-1 cells were cultured for 6 days without FBS, cell death was observed in PDTC-treated THP-1 cells (data not shown).

\section{Role of TSLP in IL-32-induced macrophage-like cells differentiation}

To investigate the direct role of TSLP in IL-32-induced macrophage-like cells differentiation, THP-1 cells were stimulated with recombinant TSLP. As shown in Figure 4A, 


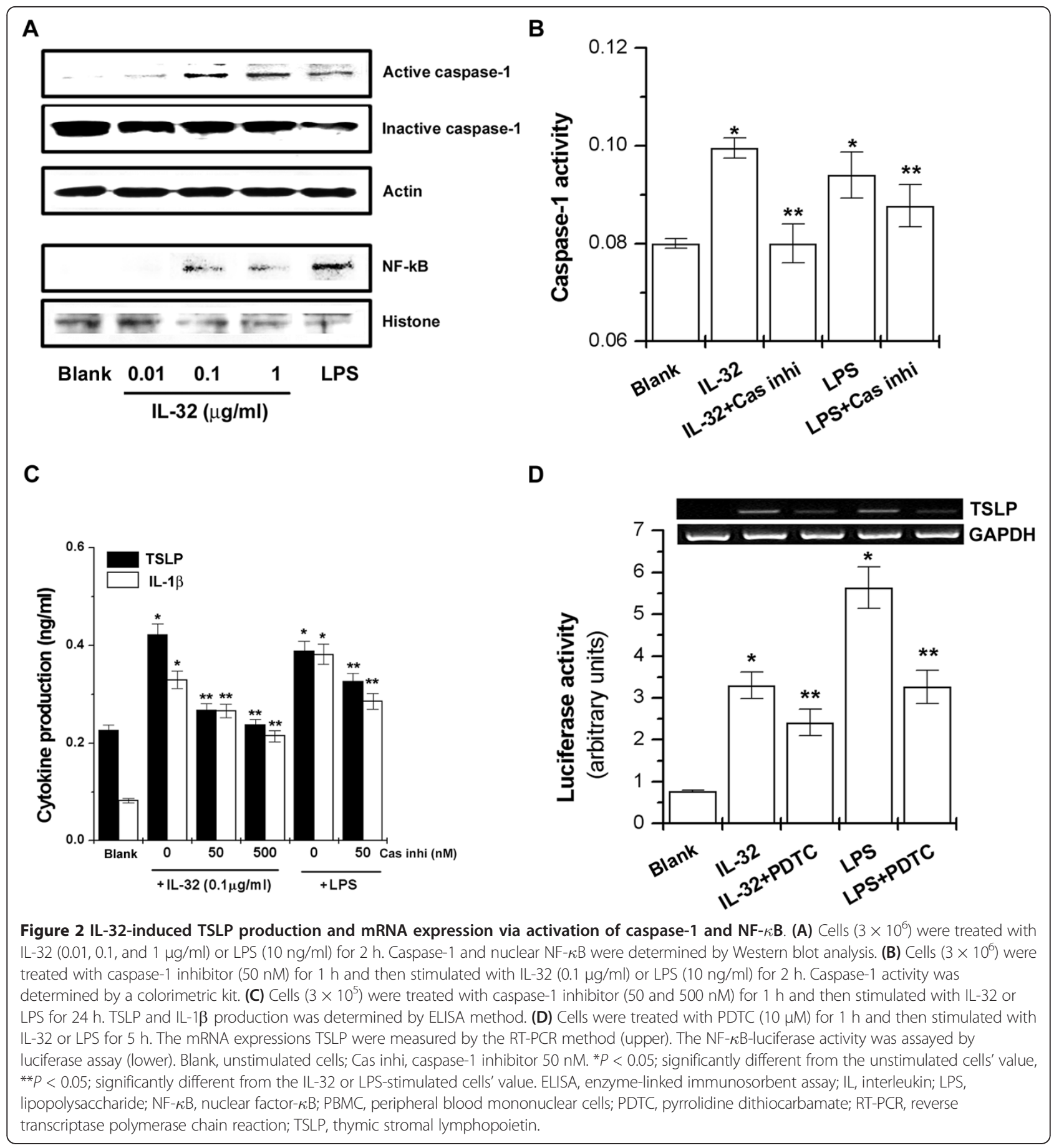

recombinant TSLP significantly increased CD11b and CD14 mRNA expression but increased CD11b and CD14 mRNA expression were reduced by neutralizing antiTSLP antibodies. The expression of CD14 mRNA by TSLP is higher than that of CD11b. Therefore, we examined the level of CD14 protein expression by TSLP. TSLP also increased expression of CD14 protein (Figure 4B). TSLP signals via TSLP receptor (TSLPR), a heterodimer of the IL-7 receptor alpha chain (IL-7R $\alpha)$ and the TSLPR chain supports differentiation and survival of various immune cells such as DC, T cells, and B cells [28]. TSLPR, which is expressed by myeloid DC, monocytes, preactivated $T$ cells, natural killer cells, and mast cells [19]. As shown in Figure 4C, TSLPR was expressed in THP-1 cells. In order to confirm whether differentiation of THP-1 cells was mediated by TSLP, we depleted TSLP in THP-1 cells 


\section{A}
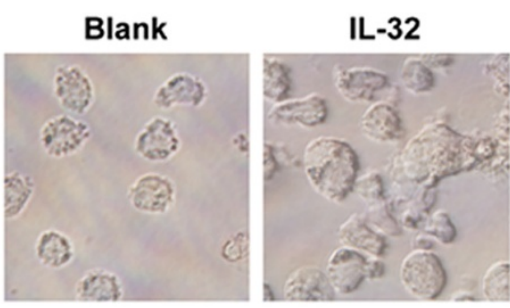

\section{IL-32+Cas-1 inhi}

B

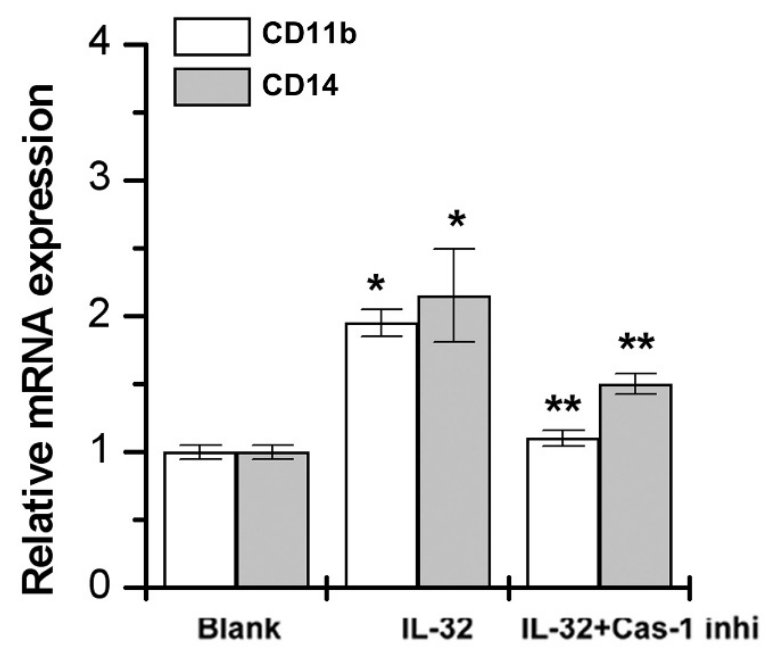

C
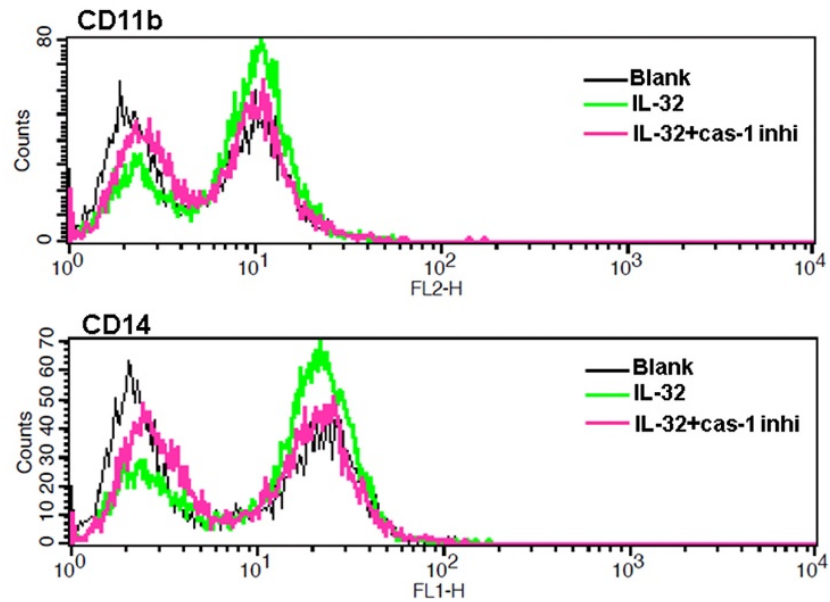

Figure 3 IL-32-induced THP-1 differentiation via activation of caspase-1. THP-1 cells were treated with recombinant IL-32 $(0.1 \mu \mathrm{g} / \mathrm{ml}) \mathrm{or}$ caspase-1 inhibitor (50 nM) for 6 days in the absence of FBS. (A) Individual THP-1 cells were photographed. (B) Real-time PCR of macrophage markers, CD11b and CD14 after simulation of THP-1 cells. (C) FACS analysis of protein expression of macrophage markers, CD11b and CD14. Blank, unstimulated cells; Cas-1 inhi, caspase-1 inhibitor. ${ }^{*} P<0.05$; significantly different from the unstimulated cells' value, ${ }^{* *} P<0.05$; significantly different from the IL-32-stimulated cells' value. (Original magnification $\times 400$ ). FACS, fluorescence-activated cell sorter; FBS, fetal bovine serum; IL, interleukin; PCR, polymerase chain reaction. 


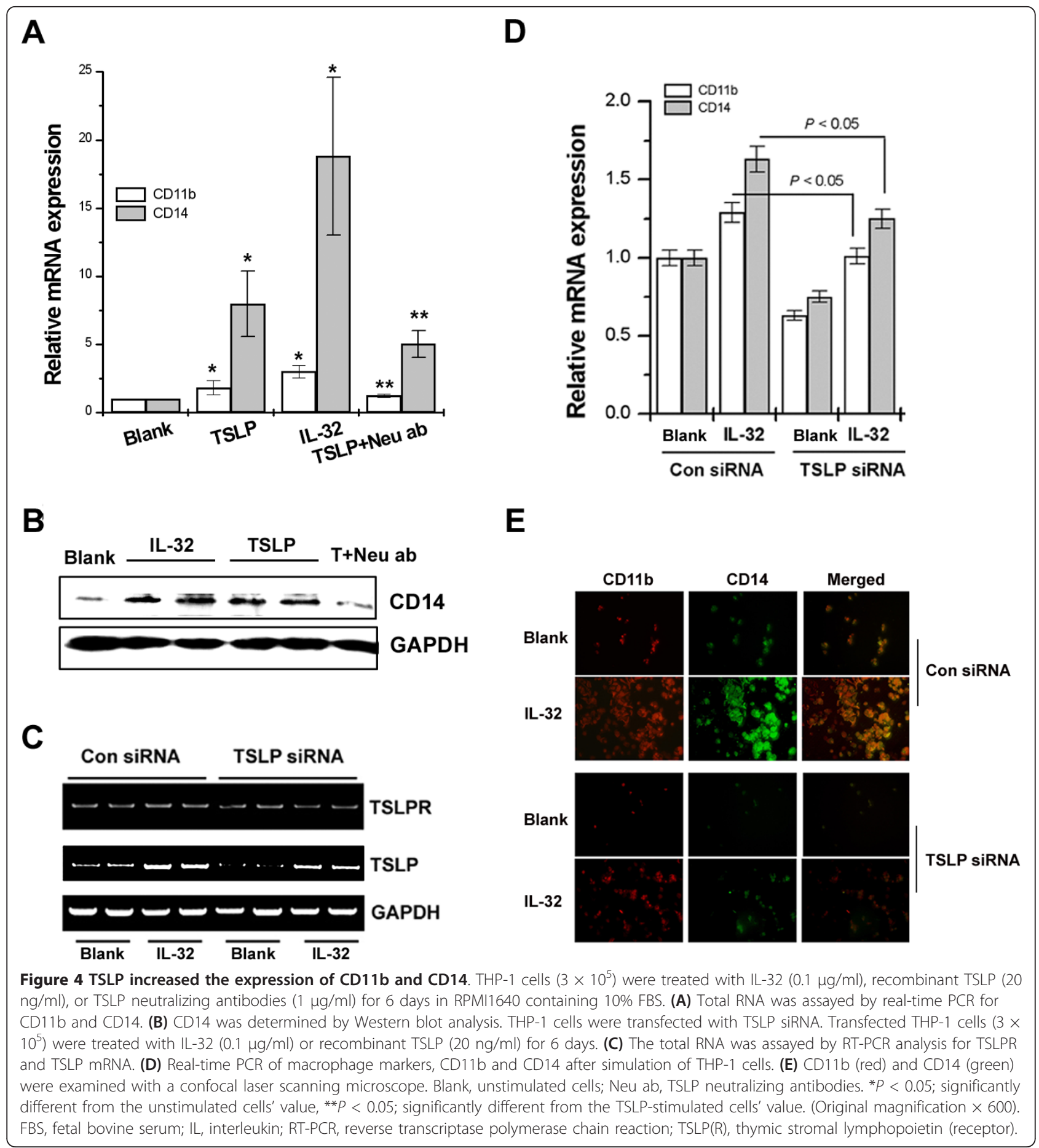

using TSLP siRNA (TSLP SMARTpool, Dharmacon Inc., Chicago, IL, USA). Messenger RNA analysis by RT-PCR revealed that TSLP was reduced (Figure 4C). The expressions of CD11b and CD14 were also decreased by TSLP siRNA (Figure 4D and 4E). Confocal laser scanning microscopic analysis clearly demonstrated that the enhanced CD11b and CD14 protein expressions were induced by treatment with IL-32, but it was markedly blocked by TSLP siRNA (Figure 4E).

\section{Effect of BT and CS on IL-32 or LPS-induced TSLP} production and mRNA expression

Chondroprotective drugs such as BT and CS is used for the treatment of arthritis such as RA and osteoarthritis. 
We assessed the regulatory effect of BT and CS on IL32 or LPS-induced TSLP production and mRNA expression. The results showed that BT and CS significantly inhibited IL-32 or LPS-induced TSLP production and mRNA expression (Figures 5A to 5D, $P<0.05$ ). CS dose-dependently inhibited LPS-induced TSLP production. BT or CS did not affect TSLP production by itself.

\section{Effect of BT and CS in IL-32 or LPS-induced caspase-1 and $\mathrm{NF}-\kappa \mathrm{B}$ activation}

We investigated whether BT and CS would influence the activation of caspase-1 induced by IL-32 or LPS in THP-1 cells. Western blot analysis for caspase-1 was performed. Caspase- 1 activation by IL-32 or LPS was decreased by the treatment of BT or CS (Figure 5E and 5F). We also estimated the effect of BT and CS on caspase- 1 activation using a caspase- 1 assay kit. Once again, this showed that caspase- 1 activity was significantly inhibited by the treatment of BT or CS (Figure 5G and 5H, $P<0.05$ ). The expression of TSLP mRNA was regulated by the transcription factor, NF- $\kappa \mathrm{B}$ [26]. Because the suppression of NF- $\kappa \mathrm{B}$ is linked with anti-inflammation, we postulated that BT and CS mediate its effects at least partly through the suppression of NF- $\kappa \mathrm{B}$ activation. To assess the regulatory mechanism of BT and CS on TSLP mRNA expression, we examined the regulatory effect of BT and CS on the translocation of NF- $\kappa$ B into the nucleus. The stimulation with IL-32 or LPS increased translocated levels of NF- $\kappa$ B in the nucleus but the translocated levels of NF- $\kappa$ B were suppressed by the treatment of BT or CS (Figure 5E and 5F).

\section{Effect of BT and CS in IL-32-induced macrophage-like cells differentiation}

Finally, we assessed the regulatory effect of BT and CS in IL-32-induced macrophage-like cells differentiation. The expression of CD11b and CD14 mRNA was analyzed by real-time PCR. BT and CS inhibited expressions of CD11b and CD14 mRNA and protein (Figure 6A and 6B). Confocal laser scanning microscopic analysis clearly demonstrated that the enhanced expression of CD11b and CD14 was induced by the treatment of IL-32, but it was markedly blocked by the treatment of BT or CS (Figure 6C). BT and CS significantly inhibited IL-32-induced TSLP mRNA expression (Figures 6D, $P<0.05$ ).

\section{Discussion}

In the present study, we demonstrated that IL-32 induced the TSLP production and mRNA expression via activation of caspase- 1 and NF- $\kappa$ B. IL-32 and TSLP also increased the differentiation of THP-1 cells. In addition, CS and BT inhibited the differentiation of THP-1 cells through inhibition of TSLP production and caspase-1 activation.
IL-32 plays an important role in host defense against microorganisms including Mycobacterium, HIV, and influenza [13,29-31]. IL-32 has also been implicated in several inflammatory disorders, including rheumatoid arthritis, Crohn's disease, atopic dermatitis, chronic obstructive pulmonary disease, and allergic rhinitis $[9,11,12,32,33]$. IL-32 expression is related with disease severity in these conditions. Recently, we have been shown that silencing of endogenous IL-32 results in the reduction of IL-6, IL-8, TNF- $\alpha$, and vascular endothelial growth factor (VEGF) [11]. TSLP produced the IL-5, IL-6, IL-13, and granulocyte macrophage colony-stimulating factor from mast cells [18]. TSLP expression correlates with markers of inflammation. TSLP-induced immune activation increased the joint destruction, because TSLPR-/-mice displayed decreased cartilage and bone erosion, decreased number of tartrate-resistant acid phophatase-positive osteoclasts, and reduced local expression of factors that are involved in tissue destruction [15]. Block of TSLP reduced the severity of collagen-induced arthritis [15]. From this, we can presuppose that TSLP produced by IL-32 plays an important role in expression of inflammatory cytokines. These properties suggest that IL-32-induced TSLP might play an important role in the amplification of inflammatory reactions such as RA. Future studies will be required to investigate whether TSLP acts as an endogenous regulator of proinflammatory cytokine production in monocytes.

It has been shown that IL-32 potentiates one or more of the intracellular pathways induced by NOD ligands. Synthetic muramyl dipeptide engagement of NOD2 results in the activation of two signaling pathways. First, NOD2 activates the serine/threonine kinase receptor-interacting protein 2/RICK/CARDIAK, and this leads to NF- $\kappa$ B activation and transcription of proinflammatory cytokine genes such as those encoding TNF- $\alpha$, IL- $1 \beta$, and IL-6 [34]. Second, the CARD domain of NOD-like receptors proteins interacts with caspase- 1 and 5 , and this interaction results in the processing of cytokine precursors such as pro-IL-1 $\beta$ and pro-IL-18 [34]. In this study, IL-32 increased the caspase- 1 and NF- $\kappa$ B activation in THP-1 cells. Caspase-1 inhibitor or NF- $\kappa$ B inhibitor reduced the IL-32-induced TSLP production and mRNA expression. Taken together, these reports imply that IL-32 induces TSLP production and mRNA expression in THP-1 cells through a signaling cascade downstream of the caspase-1 and NF- $\kappa$ B activation.

Both the innate and acquired immune systems rely heavily upon the effector and regulatory activities of monocytes and macrophages [35]. Differentiation of myeloid cells involves broad-based and tightly regulated changes in gene expression induced in response to diverse cytokines, growth factors and other agonists $[36,37]$. Expression of CD11b and CD14 is upregulated 


\section{A}

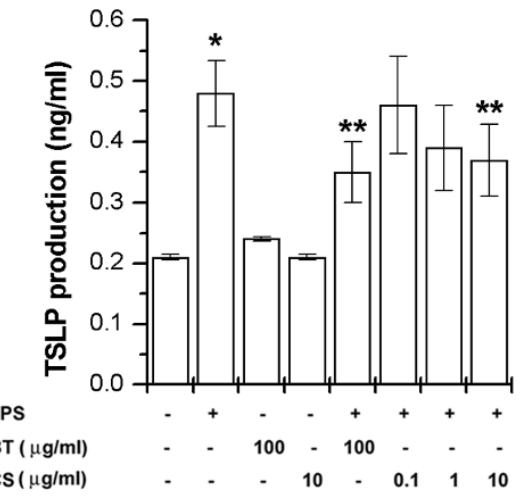

C

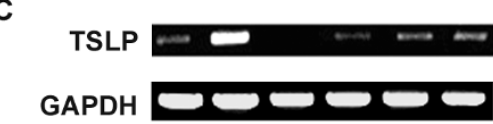

$\mathrm{BT}(\mu \mathrm{g} / \mathrm{ml}) \quad-\quad-100 \quad-100 \quad-$

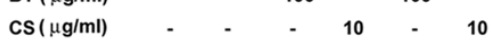

B

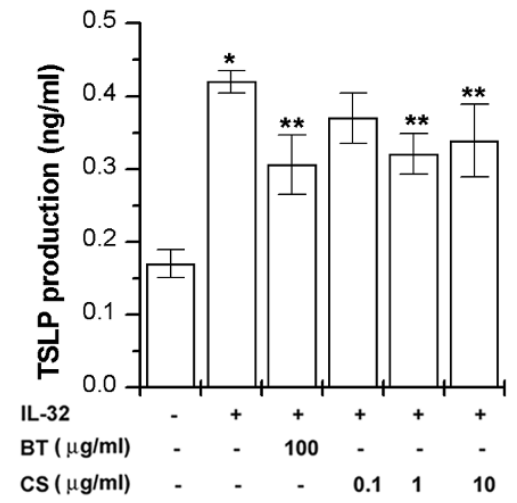

E

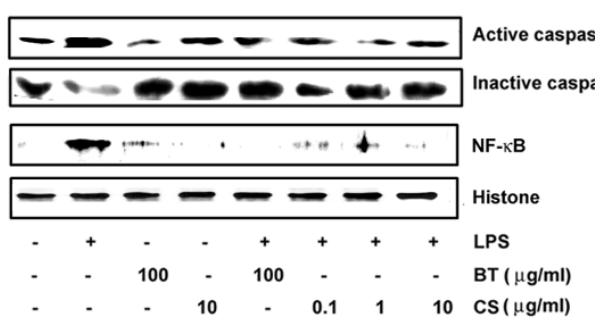

G

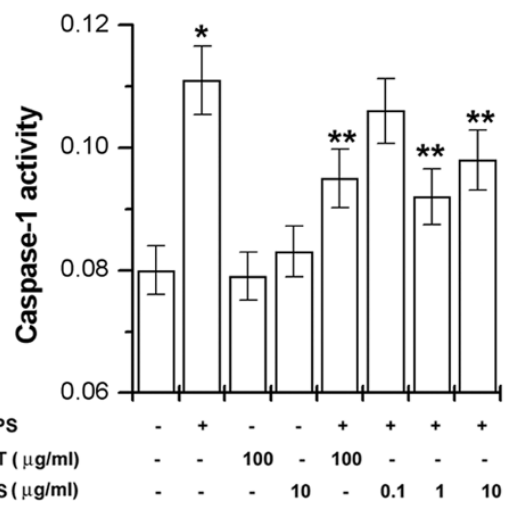

D

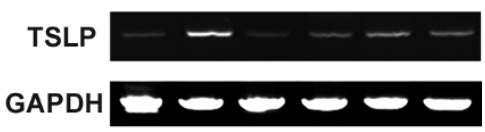

IL-32

BT $(\mu \mathrm{g} / \mathrm{ml}) \quad-\quad-100 \quad-100$

$\operatorname{cs}(\mu \mathrm{g} / \mathrm{ml}) \quad-\quad-\quad-10 \quad-10$

$\mathbf{F}$

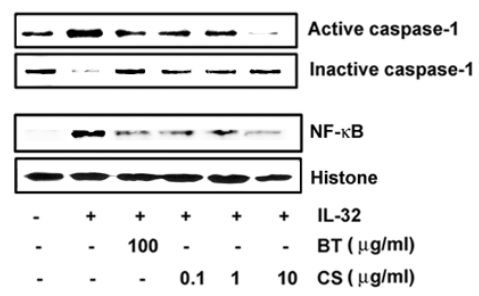

H

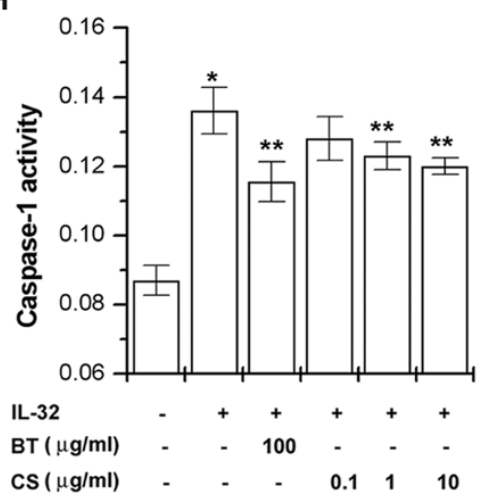

Figure $5 \mathrm{BT}$ and CS inhibited the IL-32 or LPS-induced TSLP production and mRNA expression through the inhibition of caspase-1 and NF- $\kappa$ B activation. THP-1 cells $\left(3 \times 10^{5}\right)$ were treated with BT $(100 \mu \mathrm{g} / \mathrm{ml})$ and $\mathrm{CS}(0.1,1$, and $10 \mu \mathrm{g} / \mathrm{ml})$ for $2 \mathrm{~h}$ and then stimulated with LPS $(10 \mathrm{ng} / \mathrm{ml}$, (A) or IL-32 $(0.1 \mathrm{\mu g} / \mathrm{ml}$, (B) for $24 \mathrm{~h}$. The production of TSLP in the supernatant was measured by the ELISA method. (C and D) THP-1 cells $\left(3 \times 10^{6}\right)$ were treated with BT or CS for $5 \mathrm{~h}$. The mRNA expressions of TSLP were measured by the RT-PCR method. THP- 1 cells $(3 \times$ $\left.10^{6}\right)$ were treated with BT $(100 \mu \mathrm{g} / \mathrm{ml})$ and CS $(0.1,1$, and $10 \mu \mathrm{g} / \mathrm{ml})$ for $2 \mathrm{~h}$ and then stimulated with $\mathrm{L}-32(0.1 \mu \mathrm{g} / \mathrm{ml})$ or LPS $(10 \mathrm{ng} / \mathrm{ml}) \mathrm{for} 2 \mathrm{~h}$. ( $\mathbf{E}$ and $\mathbf{F}$ ) Caspase-1 and NF- $\kappa$ B were determined by Western blot analysis. ( $\mathbf{G}$ and $\mathbf{H}$ ) Caspase-1 activity was determined by a colorimetric kit. ${ }^{*} P$ $<0.05$; significantly different from the unstimulated cells' value, ${ }^{* *} P<0.05$; significantly different from the IL-32 or LPS-stimulated cells' value. BT, BaekJeol-Tang; CS, chondroitin sulfate; ELISA, enzyme-linked immunosorbent assay; IL, interleukin; LPS, lipopolysaccharide; NF- $\kappa B$, nuclear factor$\kappa B$; RT-PCR, reverse transcriptase polymerase chain reaction; TSLP, thymic stromal lymphopoietin. 


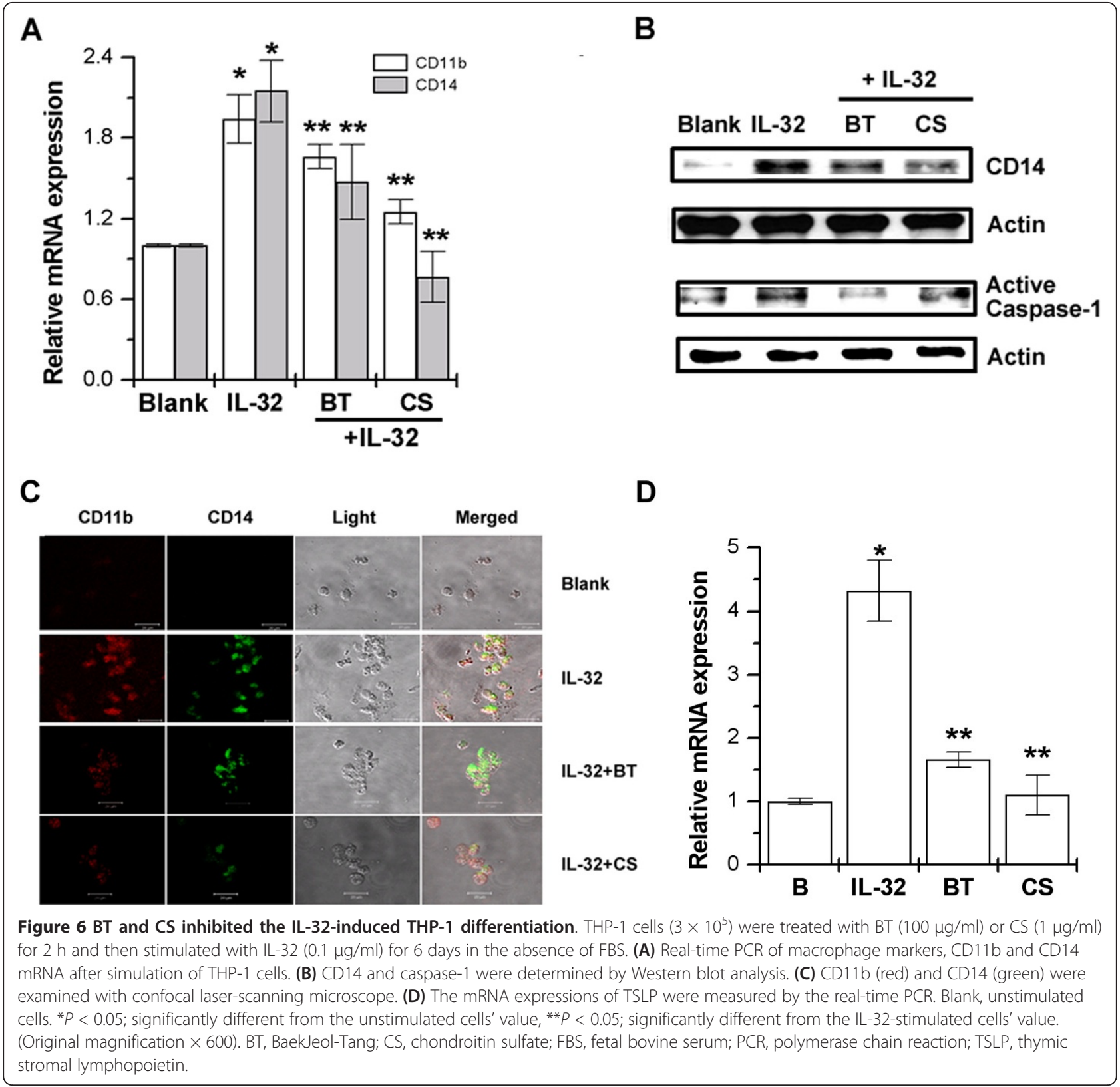

during myeloid cell differentiation. Myeloid zinc finger-1 is involved downstream of phosphatidylinositide 3-kinase in a calcitriol-induced signaling pathway leading to myeloid cell differentiation and activation of CD11b and CD14 [37]. Recent studies by Netea and colleagues reported that IL-32 induced a consistent increase in the expression of both CD1a and CD14 [27]. TSLP is capable of activating dendritic cells to promote Th2 immune responses. TSLP has also been shown to directly promote Th2 differentiation of naïve CD4 (+) $\mathrm{T}$ cell and activate natural killer T cells, basophils and other innate immune cells at the initial stage of inflammation [38]. We also observed that IL-32 induces differentiation of THP-1 cells into macrophage-like cell.
Netea et al., showed caspase-3 activation, but not caspae-1, $-8,-9$, plays an important role in monocyte differentiation [27]. However, we investigated that caspase-1 inhibitor reduced the CD11b and CD14 expression through the inhibition of TSLP production. We also showed that TSLP siRNA inhibited the monocyte differentiation. For that reason, we suggest that blockade of IL-32 and TSLP signaling may be effective in prevention and treatment in models of inflammatory arthritis.

The suppressing of TSLP production signaling in THP-1 cells may be a useful tool to reduce monocyte differentiation in inflammatory conditions. CS belongs to the class of natural complex polysaccharides and is an unbanched, 
polydisperse, complex macromolecule extracted and purified from various tissues [39]. It is a useful therapeutic agent in diseases such as inflammatory bowel diseases, artherosclerosis, Parkinson's and Alzheimer's diseases, multiple sclerosis, amyotrophic lateral sclerosis, rheumatoid arthritis, and systemic lupus erythematosus [40]. CS diminishes the expression of inflammatory proteins via inhibiting of NF- $\kappa \mathrm{B}$ nuclear translocation in chondrocyte, synovial macrophages, synoviocytes, and peripheral blood mononuclear cells [40]. In previous studies, David-Raoudi et al., reported that CS increases hyaluronan production through upregulation of the expression of hyaluronan synthases [39]. BT, a traditional Korean medicine, has long been prescribed as a treatment for joint diseases to protect injured chondrocytes. However, effect of these drugs has not been elucidated on TSLP production and monocyte differentiation. In this study, we showed that BT or CS significantly inhibited the production of TSLP, activation of caspase- 1 and NF- $\kappa \mathrm{B}$, and differentiation of monocytes in THP-1 cells. Therefore, our finding provides new evidence that chondroprotective effect caused by the treatment of BT and CS is related to the inhibition of TSLP production and monocyte differentiation.

\section{Conclusions}

In conclusion, we show for the first time that IL-32 induces TSLP production by increasing NF- $\kappa \mathrm{B}$ and caspase-1 activation. IL-32-induced TSLP induces differentiation of monocytes into macrophage-like cells with characteristic surface markers (CD11b and CD14). To our knowledge, this is also the first study to demonstrate that chondroprotective effect of BT and CS is accompanied by a regulation of TSLP production. Our results have demonstrated an essential role for the IL-32/TSLP pathway in RA. Further investigation is necessary to determine other possible mechanisms of IL-32 and TSLP and to apply it clinically in RA and other inflammatory diseases.

\begin{abstract}
Abbreviations
BT: BaekJeol-Tang; Cl: caspase-1 inhibitor; CS: chondroitin sulfate; DC: dendritic cells; DMSO: dimethyl sulfoxide; ERK: extracellular signal-regulated kinase; FACS: fluorescence-activated cell sorter; FBS: fetal bovine serum; IFN$\gamma$ : interferon- $;$; IL-32: interleukin-32; LPS: lipopolysaccharide; MAPK: mitogenactivated protein kinase; MTT: 3-(4,5-dimethylthiazol-2-yl)-2,5-

diphenyltetrazolium bromide; NF-kB: nuclear factor-KB; NOD: nucleotide oligomerization domain; PBMC: peripheral blood mononuclear cells; PDTC: pyrrolidine dithiocarbamate; RA: rheumatoid arthritis; RT-PCR: reverse transcriptase time polymerase chain reaction; siRNA: small interfering RNA; TLR: toll-like receptors; TNF: tumor necrosis factor; TSLP: thymic stromal lymphopoietin; TSLPR: TSLP receptor.
\end{abstract}

\section{Acknowledgements}

This work was supported by Kyung Hee University (KHU-20110092). The funders had no role in the study design, data collection and analysis, decision to publish, or preparation of the manuscript.

\section{Author details}

'Biochip Research Center, Hoseo University, 165, Sechul-ri, Baebang-myun, Asan, Chungnam 336-795, Republic of Korea. 'Department of Pharmacology,
College of Oriental Medicine, Kyung Hee University, 1 Hoegi-dong, Dongdaemun-gu, Seoul 130-701, Republic of Korea. ${ }^{3}$ Department of Otolaryngology, College of Medicine, Kyung Hee University, 1 Hoegi-dong, Dongdaemun-gu, Seoul, 130-701, Republic of Korea. ${ }^{4}$ High-Enthalpy Plasma Research Center, Chonbuk National University, 664-14, 1 Ga Deokjin-dong, Deokjin-gu, Jeonju, 561-756, Republic of Korea.

\section{Authors' contributions}

HJJ and HMK designed and wrote the manuscript. HJJ and SYN did the experiments and analysis. HAO did the analysis of the confocal microscopy NRH and PDM did the real-time PCR and ELISA. SYS isolated the PBMCs. MHK and YSK provided comments on the manuscript. HMK supervised the research. All authors read and approved the final manuscript.

\section{Competing interests}

The authors declare that they have no competing interests.

Received: 11 July 2012 Revised: 9 October 2012

Accepted: 27 November 2012 Published: 28 November 2012

\section{References}

1. Feldmann M, Brennan FM, Maini RN: Rheumatoid arthritis. Cell 1996, 85:307-310.

2. Kinne RW, Brauer R, Stuhlmüller B, Palombo-Kinne E, Burmester GR: Macrophages in rheumatoid arthritis. Arthritis Res 2000, 2:189-202.

3. Huber LC, Distler O, Tarner I, Gay RE, Gay S, Pap T: Synovial fibroblasts: key players in rheumatoid arthritis. Rheumatology (Oxford) 2006, 45:669-675.

4. Firestein GS, Zvaifler NJ: How important are T cells in chronic rheumatoid synovitis? II. T cell-independent mechanisms from beginning to end. Arthritis Rheum 2002, 46:298-308.

5. Kasama T, Miwa Y, Isozaki T, Odai T, Adachi M, Kunkel SL: Neutrophilderived cytokines: potential therapeutic targets in inflammation. Curr Drug Targets Inflamm Allergy 2005, 4:273-279.

6. Martinez-Gamboa L, Brezinschek HP, Burmester GR, Dorner T: Immunopathologic role of $B$ lymphocytes in rheumatoid arthritis: rationale of B cell-directed therapy. Autoimmun Rev 2006, 5:437-442.

7. Kim SH, Han SY, Azam T, Yoon DY, Dinarello CA: Interleukin-32: a cytokine and inducer of TNF alpha. Immunity 2005, 22:131-142.

8. Netea MG, Azam T, Ferwerda G, Girardin SE, Walsh M, Park JS, Abraham E, Kim JM, Yoon DY, Dinarello CA, Kim SH: IL-32 synergizes with nucleotide oligomerization domain (NOD) 1 and NOD2 ligands for IL-1 beta and IL-6 production through a caspase 1-dependent mechanism. Proc Natl Acad SCi USA 2005, 102:16309-16314.

9. Meyer N, Zimmermann M, Bürgler S, Bassin C, Woehrl S, Moritz K, Rhyner C, Indermitte P, Schmid-Grendelmeier P, Akdis M, Menz G, Akdis CA: IL-32 is expressed by human primary keratinocytes and modulates keratinocyte apoptosis in atopic dermatitis. J Allergy Clin Immunol 2010, 125:858-865.

10. Kempuraj D, Conti P, Vasiadi M, Alysandratos KD, Tagen M, Kalogeromitros D, Kourelis T, Gregoriou S, Makris M, Stavrianeas NG, Theoharides TC: IL-32 is increased along with tryptase in lesional psoriatic skin and is up-regulated by substance $\mathrm{P}$ in human mast cells. Eur J Dermatol 2010, 20:865-867.

11. Jeong HJ, Shin SY, Oh HA, Kim MH, Cho JS, Kim HM: IL-32 up-regulation is associated with inflammatory cytokine production in allergic rhinitis. J Pathol 2011, 224:553-563.

12. Joosten LA, Netea MG, Kim SH, Yoon DY, Oppers-Walgreen B, Radstake TR, Barrera P, van de Loo FA, Dinarello CA, van den Berg WB: IL-32, a proinflammatory cytokine in rheumatoid arthritis. Proc Natl Acad Sci USA 2006, 103:3298-3303.

13. Netea MG, Azam T, Lewis EC, Joosten LA, Wang M, Langenberg $D$, Meng X, Chan ED, Yoon DY, Ottenhoff T, Kim SH, Dinarello CA: Mycobacterium tuberculosis induces interleukin-32 production through a caspase-18/interferon-gamma-dependent mechanism. PLOS Med 2006, 3:e277.

14. Lee S, Kim JH, Kim H, Kang JW, Kim SH, Yang Y, Kim J, Park J, Park S, Hong J, Yoon DY: Activation of the interleukin-32 pro-inflammatory pathway in response to human papillomavirus infection and overexpressionof interleukin-32 controls the expression of the humanpapillomavirus oncogene. Immunology 2011, 132:410-420.

15. Hartgring $S A$, Willis CR, Dean CE Jr, Broere F, van Eden W, Bijlsma JW, Lafeber FP, van Roon JA: Critical proinflammatory role of thymic stromal 
lymphopoietin and its receptor in experimental autoimmune arthritis. Arthritis Rheum 2011, 63:1878-1887.

16. Bunyavanich S, Melen E, Wilk JB, Granada M, Soto-Quiros ME, Avila L, LaskySu J, Hunninghake GM, Wickman M, Pershagen G, O'Connor GT, Weiss ST, Celedón JC: Thymic stromal lymphopoietin (TSLP) is associated with allergic rhinitis in children with asthma. Clin Mol Allergy 2011, 9:e1.

17. Ziegler SF, Artis D: Sensing the outside world: TSLP regulates barrier immunity. Nat Immunol 2010, 11:289-293.

18. Allakhverdi Z, Comeau MR, Jessup HK, Yoon BR, Brewer A, Chartier S, Paquette N, Ziegler SF, Sarfati M, Delespesse G: Thymic stromal lymphopoietin is released by human epithelial cells in response to microbes, trauma, or inflammation and potently activates mast cells. J Exp Med 2007, 204:253-258

19. Park LS, Martin U, Garka K, Gliniak B, Di Santo JP, Muller W, Largaespada DA, Copeland NG, Jenkins NA, Farr AG, Ziegler SF, Morrissey PJ, Paxton R, Sims JE: Cloning of the murine thymic stromal lymphopoietin (TSLP) receptor: formation of a functional heteromeric complex requires interleukin 7 receptor. J Exp Med 2000, 192:659-670.

20. Reche PA, Soumelis V, Gorman DM, Clifford T, Liu Mr, Travis M, Zurawski SM, Johnston J, Liu YJ, Spits H, de Waal Malefyt R, Kastelein RA, Bazan JF: Human thymic stromal lymphopoietin preferentially stimulates myeloid cells. J Immunol 2001, 167:336-343.

21. Rochman I, Watanabe N, Arima K, Liu YJ, Leonard WJ: Cutting edge: direct action of thymic stromal lymphopoietin on activated human CD4 T cells. J Immunol 2007, 178:6720-6724.

22. Nagata Y, Kamijuku H, Taniguchi M, Ziegler S, Seino K: Differential role of thymic stromal lymphopoietin in the induction of airway hyperreactivity and Th2 immune response in antigen-induced asthma with respect to natural killer T cell function. Int Arch Allergy Immunol 2007, 144:305-314.

23. Watanabe N, Hanabuchi S, Soumelis V, Yuan W, Ho S, de Waal Malefyt R, Liu YJ: Human thymic stromal lymphopoietin promotes dendritic cellmediated CD4 T cell homeostatic expansion. Nat Immunol 2004, 5:426-434

24. Liu YJ: TSLP in epithelial cell and dendritic cell cross talk. Adv Immunol 2009, 101:1-25.

25. Zhang K, Shan L, Rahman MS, Unruh H, Halayko AJ, Gounni AS: Constitutive and inducible thymic stromal lymphopoietin expression in human airway smooth muscle cells: role in chronic obstructive pulmonary disease. Am J Physiol Lung Cell Mol Physiol 2007, 293:L375-382.

26. Moon PD, Kim HM: Thymic stromal lymphopoietin is expressed and produced by caspase-1/NF-KB pathway in mast cells. Cytokine 2011, 54:239-243.

27. Netea MG, Lewis EC, Azam T, Joosten LA, Jaekal J, Bae SY, Dinarello CA, Kim SH: Interleukin-32 induces the differentiation of monocytes into macrophage-like cells. Proc Natl Acad Sci USA 2008, 105:3515-3520.

28. He R, Geha RS: Thymic stromal lymphopoietin. Ann NY Acad Sci 2010, 1183:13-24.

29. Bai X, Kim SH, Azam T, McGibney MT, Huang H, Dinarello CA, Chan ED: IL32 is a host protective cytokine against Mycobacterium tuberculosis in differentiated THP-1 human macrophages. J Immunol 2010, 184:3830-3840.

30. Nold MF, Nold-Petry CA, Pott GB, Zepp JA, Saavedra MT, Kim SH, Dinarello CA: Endogenous IL-32 controls cytokine and HIV-1 production. J Immunol 2008, 181:557-565.

31. Li W, Sun W, Liu L, Yang F, Li Y, Chen Y, Fang J, Zhang W, Wu J, Zhu Y: IL32: a host proinflammatory factor against influenza viral replication is upregulated by aberrant epigenetic modifications during influenza $\mathrm{A}$ virus infection. J Immunol 2010, 185:5056-5065.

32. Shioya M, Nishida A, Yagi Y, Ogawa A, Tsujikawa T, Kim-Mitsuyama S, Takayanagi A, Shimizu N, Fujiyama Y, Andoh A: Epithelial overexpression of interleukin-32alpha in inflammatory bowel disease. Clin Exp Immunol 2007, 149:480-486.

33. Calabrese F, Baraldo S, Bazzan E, Lunardi F, Rea F, Maestrelli P, Turato G, Lokar-Oliani K, Papi A, Zuin R, Sfriso P, Balestro E, Dinarello CA, Saetta M: IL32 , a novel proinflammatory cytokine in chronic obstructive pulmonary disease. Am J Respir Crit Care Med 2008, 178:894-901.

34. Kobayashi K, Inohara N, Hernandez LD, Galán JE, Núñez G, Janeway CA, Medzhitov R, Flavell RA: RICK/Rip2/CARDIAK mediates signalling for receptors of the innate and adaptive immune systems. Nature 2002, 416:194-199.
35. Seljelid R, Eskeland T: The biology of macrophages: I General principles and properties. Eur J Haematol 1993, 51:267-275.

36. Kusmartsev S, Gabrilovich DI: Effect of tumor-derived cytokines and growth factors on differentiation and immune suppressive features of myeloid cells in cancer. Cancer Metastasis Rev 2006, 25:323-331.

37. Moeenrezakhanlou A, Shephard L, Lam L, Reiner NE: Myeloid cell differentiation in response to calcitriol for expression CD11b and CD14 is regulated by myeloid zinc finger-1 protein downstream of phosphatidylinositol 3-kinase. J Leukoc Biol 2008, 84:519-528.

38. Zhang $Y$, Zhou B: Functions of thymic stromal lymphopoietin in immunity and disease. Immunol Res 2012, 52:211-223.

39. David-Raoudi M, Deschrevel B, Leclercq S, Galéra P, Boumediene K, Pujol JP: Chondroitin sulfate increases hyaluronan production by human synoviocytes through differential regulation of hyaluronan synthases: Role of p38 and Akt. Arthritis Rheum 2009, 60:760-770.

40. Vallières $M$, du Souich $P$ : Modulation of inflammation by chondroitin sulfate. Osteoarthritis Cartilage 2010, 18:51-6.

doi:10.1186/ar4104

Cite this article as: Jeong et al:: Interleukin-32-induced thymic stromal lymphopoietin plays a critical role in macrophage differentiation through the activation of caspase- 1 in vitro. Arthritis Research \& Therapy 2012 14:R259.

\section{Submit your next manuscript to BioMed Central and take full advantage of:}

- Convenient online submission

- Thorough peer review

- No space constraints or color figure charges

- Immediate publication on acceptance

- Inclusion in PubMed, CAS, Scopus and Google Scholar

- Research which is freely available for redistribution

Submit your manuscript at www.biomedcentral.com/submit
Ciomed Central 